\title{
Issues related to infectious disease and immunization status of immigrant children including immigrants, refugees and international adoptees
}

$\mathrm{L}$

N 1992 NEARLY 61.000 CHILDREN AND YOUTH 19 YEARS OF AGE Lor under emigrated to Canada, either alone or with their families. Over half came to Ontario, $22 \%$ to Quebec, $13 \%$ to British Columbia, $7 \%$ to Alberta, $2 \%$ to Manitoba and the remainder entered other provinces and territories.

The health status of these children and youth is not always optimal. Depending on their country of origin they may have any of a number of infections including parasitic infestations, tuberculosis, human immunodeficiency virus (HIV) infection, syphilis, chronic hepatitis B carriage or dormant malaria. Their immunization status may be incomplete or unknown. Additionally some may have been immunized with ineffective vaccines which would not meet current licensure standards in Canada.

Physicians who provide care for these children and youth must be aware of what is done - and, more importantly, what is not done - as part of the entry process into Canada. Recommendations for dealing with the many issues related to their health, including those outside of the area of infectious diseases, are currently being devised. Until guidelines are available, the Infectious Disease and Immunization Committee of the Canadian Pediatric Society presents the following as information for practising physicians to ensure that false assumptions regarding the extent of health screening of immigrants are corrected.

Children entering Canada legally from abroad fall into one of three categories:

- International adoptees, sponsored by prospective parents through adoption agencies

All material presented in Pediatric Infectious Disease Notes has been reviewed and approved by the chairperson, Canadian Pediatric Society Board and representative members of the Canadian Pediatric Society Committee on Infectious Diseases and Immunization
- Refugees who leave their own country because of persecution or fear of persecution

- Immigrants who do not fall into either of the first two categories.

Health assessment is the responsibility of the Division of Immigration Health, Health and Welfare Canada. It is essential to be aware that children who enter Canada as refugees are not screened prior to arrival. The process is initiated after their first hearing which may be months after arrival into the country. For all other children including adoptees and immigrants, health screening must have been done within the 12 month interval prior to entry to Canada. The process includes a history and physical examination (including vision and hearing screening) for all individuals. Additional screens are age dependent; for children aged five years or older, dipstick analysis of urine for protein, sugar and blood, plus microscopy if any are positive; for those aged 11 or years or older, chest radiograph; for those aged 15 years or older, VDRL test.

In some instances reports of tests done to rule out infections such as HIV, hepatitis B virus and tuberculosis may be provided by the immigrant. Neither the required nor volunteered test results should ever be considered reliable. In some cases favourable test results may be purchased and in others the test is not subject to the same degree of quality control as in Canada. If indicated these tests should be repeated once in Canada. If there is doubt expert opinion should be sought.

Updating immunizations is not part of the screening process for admission to Canada. Once in Canada there is no standard process to ensure that such children receive appropriate vaccines according to recommended schedules. Guidelines for immunization of such children have been made by the National Advisory 
Committee on Immunization ${ }^{1}$ and will be published in the next edition of the Canadian Immunization Guide.

The Division of Immigration Health, Health and Welfare Canada can assume no responsibility for statements made herein.

\section{REFERENCE}

1. Statement on immunization of children with inadequate immunization records. Can Dis Weekly Rep 1990;16:1 1-2.

\section{SUGGESTED READING}

1. Bass JL, et al. Parasitology screening of Latin American children in a primary care clinic. Pediatrics 1992:89:279-83.

2. Godue CB, Gyorkos TW. Intestinal parasites in refugee claimants: A case study for selective screening? Can $J$ Public Health 1990:81;191-5.

3. Hershow RC. Hadler SC. Kane MA. Adoption of children from countries with endemic hepatitis B: Transmission, risks and medical issues. Pediatr Infect Dis $J$ 1987:6:431-7.
4. Hostetter MK, et al. Medical evaluation of internationally adopted children. $N$ Engl J Med 1991;325:479-85.

5. Hyani KC. Pickering L. Screening of immigrant children for infectious discases. Adv in Ped Infect Dis 1991;6:91-110.

6. Jenista JA. Disease in adopted children from Romania. JAMA 1992:268:600-1.

7. Johnson DE, Miller LC, Iverson S, et al. The health of children adopted from Romania JAMA 1992:83:559-64.

8. Lange WR, Warnock-Eckhart E, Bean ME. Mycobacterium tuberculosis infection in foreign born adoptees. Pediatr Infect Dis 1989;8:625-9.

9. Nordenfelt E, Dahlquist E. HBsAg positive adopted children as a cause of intrafamilial spread of hepatitis B. Scand J Infect Dis 1978;10:161-3.

Lee Ford-Jones, MD

Toronto, Ontario

Barbara Law, MD Winnipeg, Manitoba 


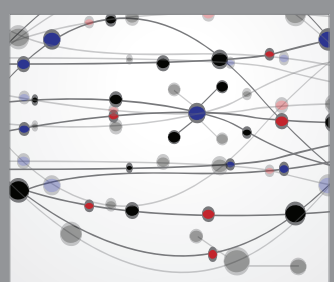

The Scientific World Journal
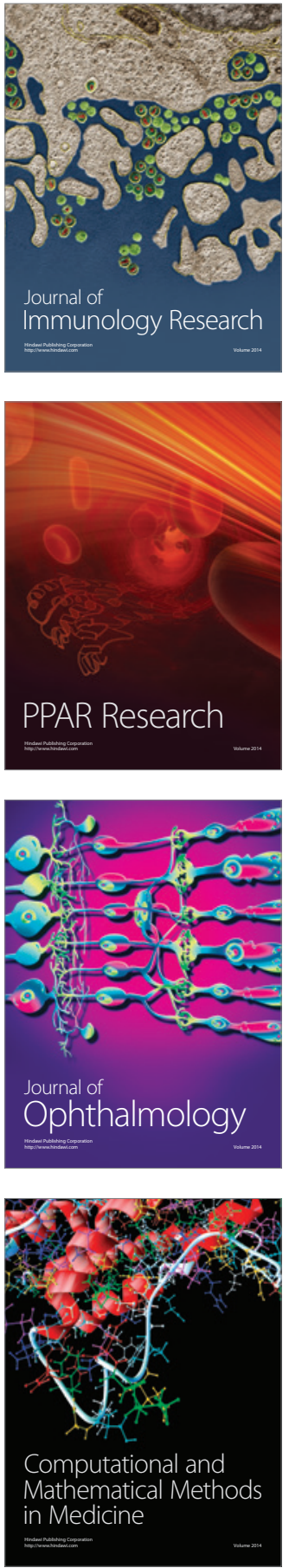

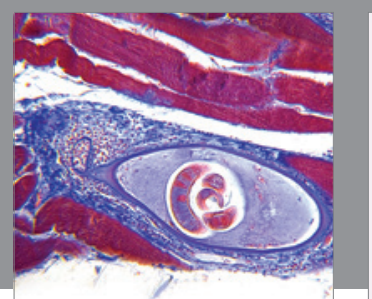

Gastroenterology Research and Practice

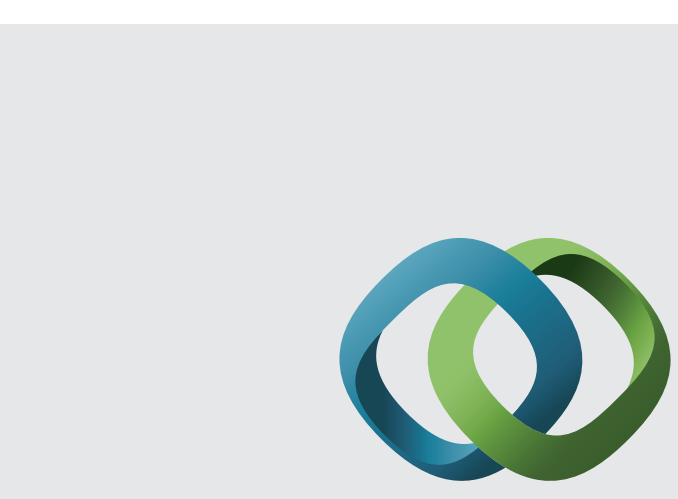

\section{Hindawi}

Submit your manuscripts at

http://www.hindawi.com
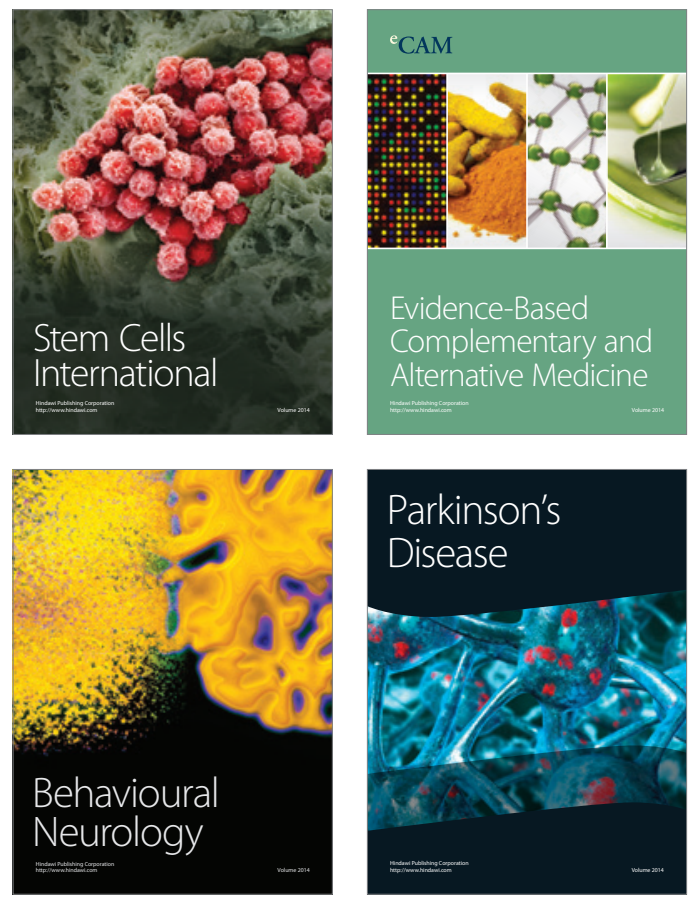
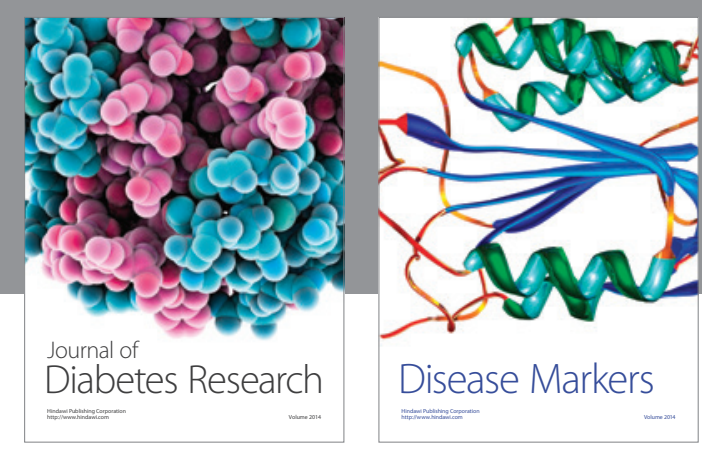

Disease Markers
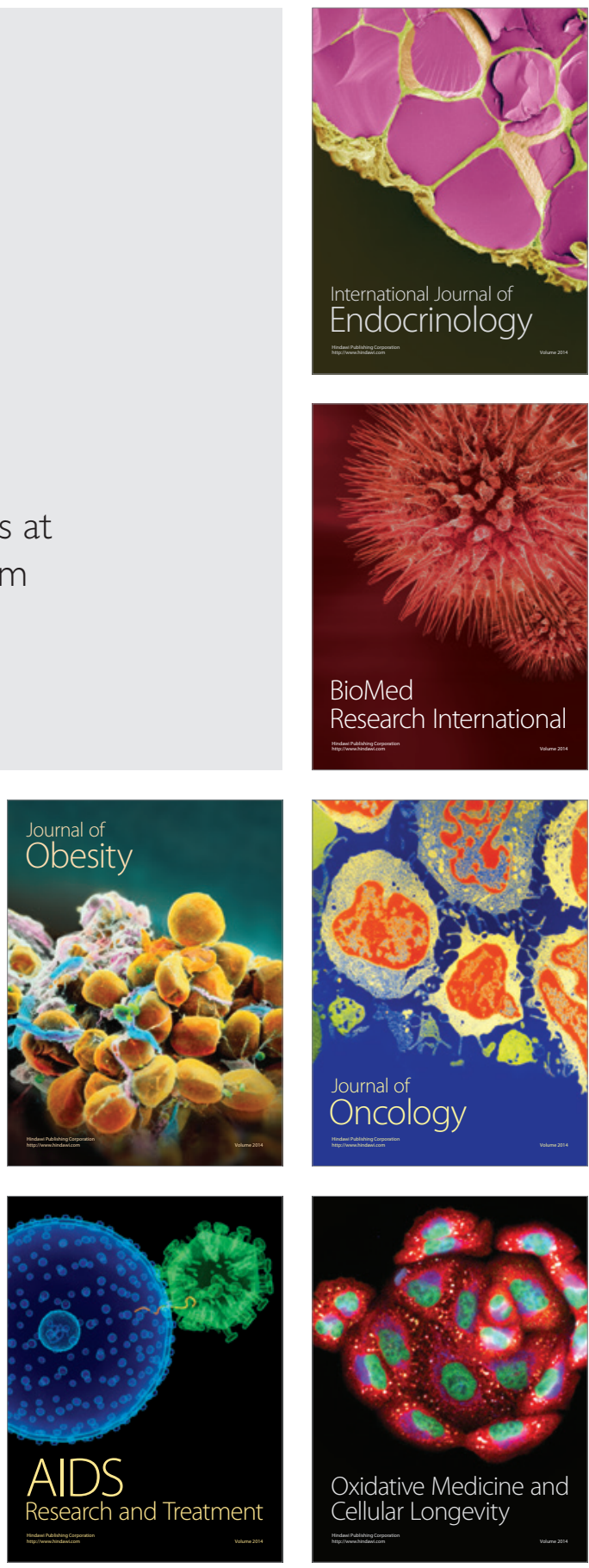